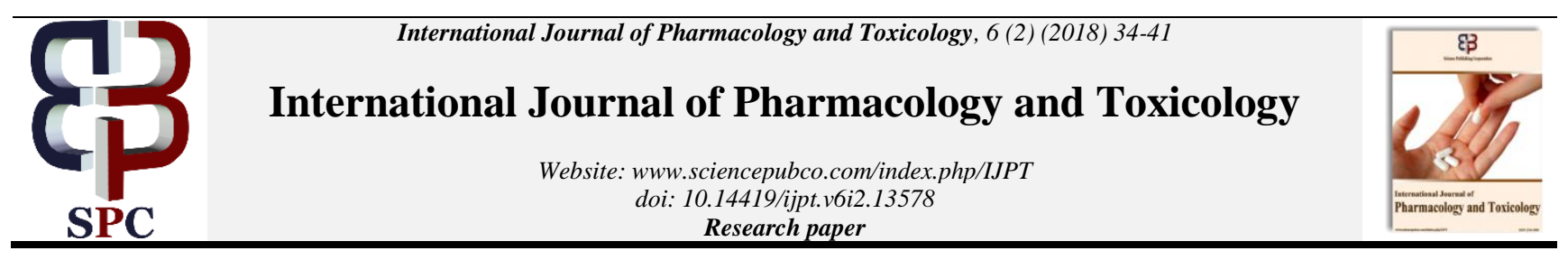

\title{
In Vitro Anti-cholinesterase and Cognitive Enhancing Properties of Essential Oils from Piper nigrum L. and Monodora myristica (Gaertn) Dunal
}

\author{
Olawuni I. J. ${ }^{1,}$ *, Ndoni S. A. ${ }^{1,2}$, Esada E. E. ${ }^{1}$, Bamidele F. S ${ }^{1}$, Obuotor E. M $^{1}$ \\ ${ }^{1}$ Department of Biochemistry and Molecular Biology, Obafemi Awolowo University, Ile-Ife, Osun State, Nigeria \\ ${ }^{2}$ Department of Biochemistry, Niger Delta University, Wilberforce Island, Bayelsa State, Nigeria \\ *Corresponding author E-mail: olawunij@ gmail.com
}

\begin{abstract}
Aging in humans generally is associated with deterioration of cognitive abilities, particularly of learning and memory leading to dementia, including Alzheimer's disease. A number of herbal medicines are reported to improve brain function and intelligence. In the present study, the ameliorating effects of essential oil extracted from Piper nigrum and Monodora myristica on learning and memory in Scopolamine induced amnesic mice were determined using two cognitive behavioural paradigms: the Step-Through Passive Avoidance and MorrisWater Maze test. Essential oils were obtained by hydro-distillation using a Clavenger-type apparatus and their profiles analyzed by GCMS. Inhibitory effects on AChE and BuChE were investigated by Ellman's method. The animals were assessed for performance by measuring the Step-Through Latency Time (SLT) and Escape Latency Time (ELT). Brain cholinesterase activities were assayed in brain tissues from the mice. The results showed that M. myristica and P. nigrum oils were characterized by $51(94.76 \%)$ and 61 (90.65\%) components, respectively. M. myristica is dominated by $\alpha$-phellandrene (18.13\%), while P. nigrum is dominated by $\beta$-pinene (5.92\%) and caryophyllene $(4.55 \%)$. Both oils at $416 \mu \mathrm{g} / \mathrm{ml}$ elicited significant inhibitory $(\mathrm{p}>0.05)$ activity with M. myristica exhibiting a stronger inhibition against $\mathrm{AChE}$ and BuChE than P. nigrum. This trend was also exhibited significantly ( $>0.05)$ in both ELT and the SLT when compared to scopolamine-treated group. In conclusion, the seeds of M. myristica and P. nigrum are potential sources of active metabolites with anticholinesterase and cognition enhancing properties, but M. myristica exhibited a higher activity.
\end{abstract}

Keywords: Anti-Cholinesterase; Essential Oil; Piper Nigrum; Monodora Myristica; and GC-MS

\section{Introduction}

Alzheimer's disease (AD) is an age-associated neurodegenerative disorder characterized by progressive loss of memory and cognition (Figueiro et al., 2011), and by the presence of extracellular (Rauk, 2009) and intracellular (Knobloch et al., 2007; La Ferla et al., 2007) plaques of $\beta$-amyloid peptide $(\mathrm{A} \beta)$, with intracellular tangles of hyper-phosphorylated tau protein (Ballatore et al., 2007). AD leads to loss of forebrain cholinergic neurons and a pronounced fall in acetylcholine levels (Auld et al., 2002), resulting in devastating cognitive impairment (Pimplikar, 2009). In fact, in animal models and humans alike, the association between plaques of $A \beta$ densities and the degree of cognitive deficiency is not always a clear-cut (Caughey and Lansbury, 2003).

$\mathrm{A} \beta$ is a toxic pro-inflammatory agent that causes neuro-inflammation in the brain (Tuppo and Arias, 2005) which are mediated by activation of microglial cells contributing to neurodegenerative processes such as it occurs in AD (Dheenet al., 2007; Kashaniet al., 2011). Inflammatory mediators (Strohmeyer and Rogers, 2001), defect in cholinergic transmission (Lahiriet al., 2002) and glutamateinduced neurotoxicity (Bourin et al., 2003) have been demonstrated to be involved in $\mathrm{AD}$. The clinical symptoms of $\mathrm{AD}$ is mainly memory impairment and loss of spatial memory (Burin et al., 2003; Keshena et al., 2011).
Memory function is likely to be formed by numerous discrete neural networks that can be disrupted by the pathophysiological processes in $\mathrm{AD}$ (Celone et al., 2006). The hippocampus, a well-known brain region involved in memory consolidation, is especially susceptible to AD. Early degenerative symptoms including significant deficiency in the performance of hippocampal-dependent cognitive abilities such as spatial learning and memory have been reported (Yamin, 2009).

Scopolamine, a muscarinic cholinergic receptor antagonist, serves as a useful pharmacological tool in producing a model of partial amnesia (Bartus, 2000; Sun et al., 2007; Wang et al., 2010). Muscarinic and nicotinic acetylcholine receptors mediate the action of acetylcholine (Ach). Clinical investigation of AD patients does not indicate changes in number and function of muscarinic acetylcholine receptors. However, a significant decrease in nicotinic acetylcholine receptors density has been reported for the cerebral cortex and hippocampus, two major areas that are involved in learning and memory processes (Hefco et al., 2003).

Plant essential oils have been used to improve health and well-being of humans which is an age-long practice. Aromatherapy, non-pharmacological therapy, is currently used worldwide in the management of chronic pain, depression, anxiety as well as cognitive, sleep and stress-related disorders (Savelev et al., 2004; Anekonda and Reddy, 2005; Hritcu et al., 2012; Natarajan et al., 2013). In a recent study, Hritcu et al. (2012) reported that dementia patients of the AD type showed significant improvement in cognitive performance following aromatherapy consisting of rosemary and lemon essential 
oils. Numerous studies have shown that essential oils from a variety of plant species such as Pinus spp (Ustun et al., 2012), Geidiella acerosa (Syad et al., 2012), Hedychium gardnerianum (Arruda et al., 2012) do possess both anticholinesterase and antioxidant properties. These properties have been demonstrated to be as a result of synergistic properties of constituents in the essential oils which were mainly monoterpenes and sesquiterpenes (Arruda et al., 2012).

In the southern part of Nigeria and perhaps in the southern part of the West African sub-region, the use of aromatic plants as spices for culinary purposes is quite popular. Piper nigrum (black pepper) and Monodora myristica (calabash nutmeg) are common spices used for the preparation of the traditional cuisine known as "pepper soup" which is often recommended, owing ostensibly for its health promoting benefits, for elderly persons, nursing mothers shortly after delivery and persons suffering from discomfort associated with cold-weather induced conditions. These benefits include: longevity, anti-aging, anti-fatigue, cognitive enhancement, anti-diabetic properties. However, this claim has not yet been subjected to rigorous experimental and clinical investigation for the purpose of validation. Thus, there is the need to carry out experimental studies with a view to give scientific backing and possibly elucidate the biochemical mechanism of action of the phyto-constituents in the seed essential oils. Hence, the aim of this study is to determine the chemical composition as well as evaluate the anti-cholinesterase and possible cognitive enhancing properties of the essential oils obtained from the seeds of $\mathrm{P}$. nigrum and M. myristica.

\section{Materials and methods}

\subsection{Materials}

Electric eel acetylcholinesterase (AChE), horse serum butyrylcholinesterase (BuChE), acetylthiocholine iodide (ATChI), butyrylthiocholine iodide $(\mathrm{BTChCl})$ and 5, 5'-dithio-bis-nitrobenzoic acid (DTNB), physostigmine hemisulfate (Eserine) and scopolamine hydrobromide were purchased from Sigma Chemical Company, St Louis, Missouri, USA. All other chemicals and solvents used, except otherwise stated, were of analytical grade.

The seeds of P. nigrum and M. myristica were purchased from the local market at Ile-Ife, Osun State, Nigeria and authenticated at the Herbarium of the Department of Botany, Obafemi Awolowo University, Ile-Ife.

\subsection{Experimental animals}

Adult inbred albino mice of both sexes weighing between 20-33 g were obtained from the Animal House, College of Health Sciences, OAU, Ile-Ife. The animals were kept under ambient conditions in metal cages and acclimatized to laboratory conditions for two weeks before the commencement of the experiment. The animals were randomly selected into ten groups (five groups for the Passive Avoidance Test and five for the Morris Water-Maze Test) of five animals per group. Food was given in form of dry pellet (AJB Animal Feeds, Ile-Ife) and water was provided ad libitum.

\subsection{Methods}

Fifty grams of the dried seeds were powdered and mixed with 500 $\mathrm{ml}$ of doubly distilled water and the oil isolated by hydro-distillation using a Clevenger-type apparatus over $5 \mathrm{~h}$. The obtained oil was separated from the water and dried over anhydrous sodium sulphate, with nitrogen gas bubbled through it. The oil was then stored in a freezer prior to further analysis. This process was repeated four times.

\subsection{Gas chromatography and mass spectrometry (GC-} MS) analysis
The analysis of the essential oil obtained was performed using Agilent GC-7890A series Gas Chromatograph equipped with a flame ionization detection (FID) and DB-1 fused silica capillary column ( $30 \times 0.25 \mathrm{~mm}$ i.d, film thickness $0.25 \mu \mathrm{m}$ ). The initial oven temperature was held at $80^{\circ} \mathrm{C}$ for $5 \mathrm{~min}$, and increased at the rate of $15^{\circ} \mathrm{C} / \mathrm{min}$ to $250^{\circ} \mathrm{C}$. Helium was used as the carrier gas at a flow rate of $1 \mathrm{ml} / \mathrm{min}$, and the sample size was $0.1 \mu \mathrm{l}$, split ratio, 50:1. The percentage composition of the essential oil was determined with a Class-GC computer programme and the relative percentages of the oil constituents were expressed as percentages by peak area normalization. For the GC-MS detection a tandem Mass Spectrophotometer (Model 5975C VLMSD), using the injector (Model 7683B Agilent Technology) with an electron ionization system with ionization energy of $70 \mathrm{eV}$ was used. The samples were diluted at a ratio $1: 100, \mathrm{v} / \mathrm{v}$ in dichloromethane and $1.0 \mu \mathrm{l}$ were injected manually in the split-less mode. Volatile components were identified based on GC retention indexes calculated by using n-hydrocarbons and mass spectra by computerized matching of essential oil compounds with the National Institute of Standards and Technology (NIST), Timberland Regional Library (TRLIB) and Wiley libraries as well as by comparison of the fragmentation patterns of the mass spectra with those reported in the literature.

\subsection{In vitro anti-cholinesterase assays}

Anti-cholinesterase, AChE and BuChE inhibiting activities of the essential oils were determined by using a modified method of Ellman et al. (1961) as described by Obuotor (2004). The oil extract was prepared in a stock solution of $2 \%$ Tween-20 in a buffer and was used for the cholinesterase inhibition assay. In a 96-well plate was added $240 \mu \mathrm{l}$ of buffer ( $50 \mathrm{mM}$ Tris-HCl, pH 8.0,) and $20 \mu \mathrm{l}$ of varying concentrations of the test samples $(10,5,2.5$ and 1.25 $\mathrm{mg} / \mathrm{ml}$ ) dissolved in $2 \%$ Tween-20, $20 \mu \mathrm{l}$ of the enzyme preparation $\left(2.55 \times 10^{-3}\right.$ units $\left./ \mu 1\right)$, the reaction mixture was then incubated for $30 \mathrm{~min}$ at $37^{\circ} \mathrm{C}$, after which $20 \mu \mathrm{l}$ of $10 \mathrm{mM}$ DTNB was added. The reaction was initiated by the addition of $20 \mu \mathrm{l}$ of $25 \mathrm{mM}$ ATChI or $\mathrm{BTChCl}$. The rate of hydrolysis of ATChI or BTChCl was then determined spectrophotometrically by measuring the change in the absorbance per minute $(\Delta \mathrm{A} / \mathrm{min})$ due to the formation of the yellow 5-thio-2-nitrobenzoate anion at $412 \mathrm{~nm}$ over a period of $4 \mathrm{~min}$ at 30 $\mathrm{s}$ interval. A solution of $2 \%$ Tween-20 was used as negative control and Eserine prepared in buffer was used as the positive control. All assays were carried out in triplicate.

The percentage inhibition (I\%) of test sample was obtained using the formula:

$\mathrm{I} \%=\left[\left(\mathrm{V}_{0}-\mathrm{V}_{\mathrm{I}} / \mathrm{V}_{\mathrm{O}}\right] \times 100\right.$

Where:

$\mathrm{I} \%=$ percentage inhibition; $\mathrm{V}_{\mathrm{I}}=$ enzyme activity in the presence of test sample; $\mathrm{V}_{\mathrm{O}}=$ enzyme activity in the absence of test sample

\subsection{Administration of test compounds and drug}

The potentials of the essentials oils to enhance learning and memory in vivo in animal models using the mice was tested using the Passive Avoidance Test and the Morris Water-Maze Test as described by Sennuga (2007). For these tests, $0.2 \mathrm{ml}$ of different concentration $(50,100$ and $200 \mathrm{mg} / \mathrm{kg}$ bwt, o.p.) of oil extract (prepared as a solution of 2\% Tween-20 was administered orally post training for 7 days in both the Morris Water-Maze and Passive Avoidance Test experiment. On the $7^{\text {th }}$ day, amnesia was induced by Scopolamine hydrobromide $(0.4 \mathrm{mg} / \mathrm{kg}$ bwt, i.p.) in these experiments (Das et al., 2002). Piracetam (10 mg/kg bwt, i.p.) was used as standard drug. The animals were subjected to acquisition test after the treatments.

\subsection{Passive shock avoidance paradigm}

Passive avoidance behavioral test based on negative reinforcement was used to examine the long-time memory (Dhingra et al., 2004). The apparatus consisted of acrylic box $(24 \mathrm{~cm} \times 32 \mathrm{~cm} \times 18 \mathrm{~cm})$ 
with a copper grid floor and a wooden platform fixed in the centre of the box. Electric shocks $(26 \mathrm{~V})$ were delivered to the grid floor for $5 \mathrm{~s}$ with an isolated pulse stimulator. At the beginning of the training, mice were placed in the light chamber to habituate for 3 $\min$. When the animal steps through from the light to dark chamber, electric foot shocks ( $26 \mathrm{~V}, 0.2 \mathrm{amp}$ for $5 \mathrm{~s}$, electric pulse simulator) were delivered to the grid floor.

The step-through latency time (SLT) from the light to dark compartment were monitored and recorded for $3 \mathrm{~min}$ as an index for learning, acquisition or memory retention for each of the animal in all the groups. The criteria/index for amnesic/cognitive activity was taken as an increase in SLT on the retention test in comparison with the acquisition test. After the training and administration of test sample (oil/piracetam), an acquisition test trial was carried out to verify the acquisition skills of the mice based on the training measured out to them, thereafter, a retrograde amnesia was induced by administration of Scopolamine $(0.4 \mathrm{mg} / \mathrm{kg}$ i.p.) $5 \mathrm{~min}$ after this test in all extract treated group, Piracetam group as well as Scopolamine only-treated group except the control which was administered with the normal saline containing $2 \%$ Tween- $20(\mathrm{n}=5)$. All animals were then exposed to a second test (retention test) $1 \mathrm{~h}$ after drug administration.

\subsection{Morris water-maze test (MWT)}

The MWT is a memory test paradigm used to test spatial memory on animal models. Thus the ability of the essential oils to reverse scopolamine-induced amnesia was evaluated in the MWT (Morris, 1984). In this study, the mice were pre-treated orally with different concentration $(50,100,200 \mathrm{mg} / \mathrm{kg}$, bwt) of the oil extract for 7 days On the $7^{\text {th }}$ day, amnesia was induced by administration of scopolamine $(0.4 \mathrm{mg} / \mathrm{kg}$ bwt, i.p). Ninety minutes after administration of Scopolamine, each animal was subjected to the acquisition test followed by a retention test $24 \mathrm{~h}$ after.

The test apparatus consisted of a large circular bowl $(65 \mathrm{~cm}$, i.d, and $40 \mathrm{~cm}, \mathrm{~h}$ ) filled with water to three-quarter mark (55 litres) and maintained at ambient temperature. The water was made opaque by the addition of evaporated milk. The pool was divided into four equal quadrants, and a removable black plastic platform $(10 \mathrm{~cm} \times 5$ $\mathrm{cm})$. The platform which was to serve as an escape refuge from the water was submerged to a level of $1 \mathrm{~cm}$ below the water level at the centre of one quadrant. The platform was not visible to the mice and remained in one location for a trial. The training phase of the WaterMaze Testing consisted of two trials per day. At the start of testing on day 1, each mouse was placed in the water with its forepaws touching the tank wall, at one of four equally spaced points around the pool. Starting release points were counter-balanced alternately near or far from the platform across subjects and groups. The mouse was allowed $120 \mathrm{~s}$ to locate the hidden platform. A trial terminates when the animal reaches the platform and remains on the platform for $20 \mathrm{~s}$. If the animal does not locate the platform within this time frame, the animal will then be guided to the platform and made to remain there for at least $20 \mathrm{~s}$. Thereafter the animal was removed from the platform, dried and returned to its cage for the next trial. The criteria/index for amnesic/cognitive activity was taken as increase/decrease in escape latency time (ELT) on retention test (second trial) in comparison with the acquisition test (first trial).

\subsection{Statistical and data analysis}

All data obtained were subjected to descriptive statistical calculation using GraphPad® Instat Statistical Package (Prism 5) and expressed as mean values \pm standard error of mean of multiple measurements ( $\mathrm{n}=$ usually between 3 and 6$)$. The $\mathrm{IC}_{50}, \mathrm{~K}_{\mathrm{m}}, \mathrm{V}_{\max }$ values were estimated from graphical linear and non-linear regression plots. The Kinetic parameters $K_{i}$ was calculated from the slope of the inhibition curve by the equation $\left\{\right.$ slope $=\mathrm{K}_{\mathrm{m}} / \mathrm{V}_{\max }\left(1+\left[\mathrm{I}_{0}\right] / \mathrm{K}_{\mathrm{i}}\right.$, . Data calculated for specific activity of $\mathrm{AChE}$ in the brain from the in vivo experiments, the SLT and ELT in the Passive Avoidance and MWT experiments were subjected to analysis of variance (ANOVA) followed by a Student's Neumans-Keuls post-test to ascertain differences between treatment groups. The level of significance was chosen as $\mathrm{p}<0.05$.

\section{Results}

\subsection{Essential oils}

The yield of essential oil obtained from M. myristica and P. nigrum were $3.64 \pm 0.86 \%$ and $0.33 \pm 0.04 \%$ respectively, based on the dry weight. A total of 51 components were detected in essential oils obtained from M. myristica while in P. nigrum only 61 compounds were detected. The oil from M. myristica contained a complex mixture consisting mainly of monoterpenes $(52.52 \%)$; sesquiterpenes (3.33\%); oxygenated monoterpenes $(3.25 \%)$ and oxygenated sesquiterpenes $(4.55 \%)$. However, a significant portion $(26.13 \%)$ of total composition could not be identified. The major constituents detected in M. myristica were $\alpha$-phellandrene $(18.13 \%), \alpha$-pinene (7.16\%), other components were present at less than $2.0 \%$ (Table 4.1). P. nigrum essential oil contained a complex mixture of monoterpenes $(22.76 \%)$ and sesquiterpene hydrocarbons $(12.41 \%)$ and oxygenated monoterpenes $(0.66 \%)$ and oxygenated sesquiterpene $(1.66 \%)$; with over $50 \%$ not identified. The major constituents detected in $\mathrm{P}$. nigrum were $\beta$-pinene $(5.92 \%), 2,4$-quinolinediol (4.74), caryophyllene $(4.55 \%)$, limonene $(3.94 \%),(+)-4$ carene (3.88\%), $\alpha$-pinene $(3.58 \%), \alpha$-cubebene $(3.25 \%)$, Copaene $(2.23 \%)$ and Ylangene $(2.11 \%)$ with the rest of the constituents less than 2.0 $\%$ (see Table 1).

Table 1: The Essential Oil Constituents of Monodora Myristica

\begin{tabular}{|c|c|c|c|}
\hline SN & Compound & RT & $\%$ Peak Area \\
\hline 1 & p-Xylene & 4.123 & 0.22 \\
\hline 2 & $\alpha$-Thujene & 5.061 & 4.71 \\
\hline 3 & $\alpha$-Pinene & 5.187 & 7.16 \\
\hline 4 & 1,3,5-trimethylbenzene & 5.559 & 0.24 \\
\hline 5 & $\beta$-Pinene & 5.730 & 0.75 \\
\hline 6 & $\beta$-Terpinene & 6.068 & 5.05 \\
\hline 7 & $\alpha$ Phellandrene & 6.291 & 18.13 \\
\hline 8 & Cymene & 6.600 & 16.26 \\
\hline 9 & Trans- $\beta$-Ocimene & 6.743 & 0.22 \\
\hline 10 & $\gamma$-Terpinene & 6.858 & 0.21 \\
\hline 11 & Octanoic acid & 7.396 & 3.15 \\
\hline 12 & Isopulegol & 7.607 & 0.81 \\
\hline 13 & Terpinen-3-ol & 7.808 & 0.47 \\
\hline 14 & Cis-Z- $\alpha$-Bisabolene epoxide & 7.865 & 0.45 \\
\hline 15 & 2-Amino-4-methylbut-2-enenitrile & 8.076 & 0.27 \\
\hline 16 & 3,5-dimethyl-Cyclohexene & 8.111 & 0.52 \\
\hline 17 & 10-Dodecyn-1-ol & 8.231 & 0.32 \\
\hline 18 & Alpha,alpha-3-Cyclohexene-1-methanol & 8.380 & 1.36 \\
\hline 19 & Alpha-phenyl-Benzene ethanol & 8.557 & 7.66 \\
\hline 20 & Benzenepropanal & 8.849 & 1.18 \\
\hline
\end{tabular}




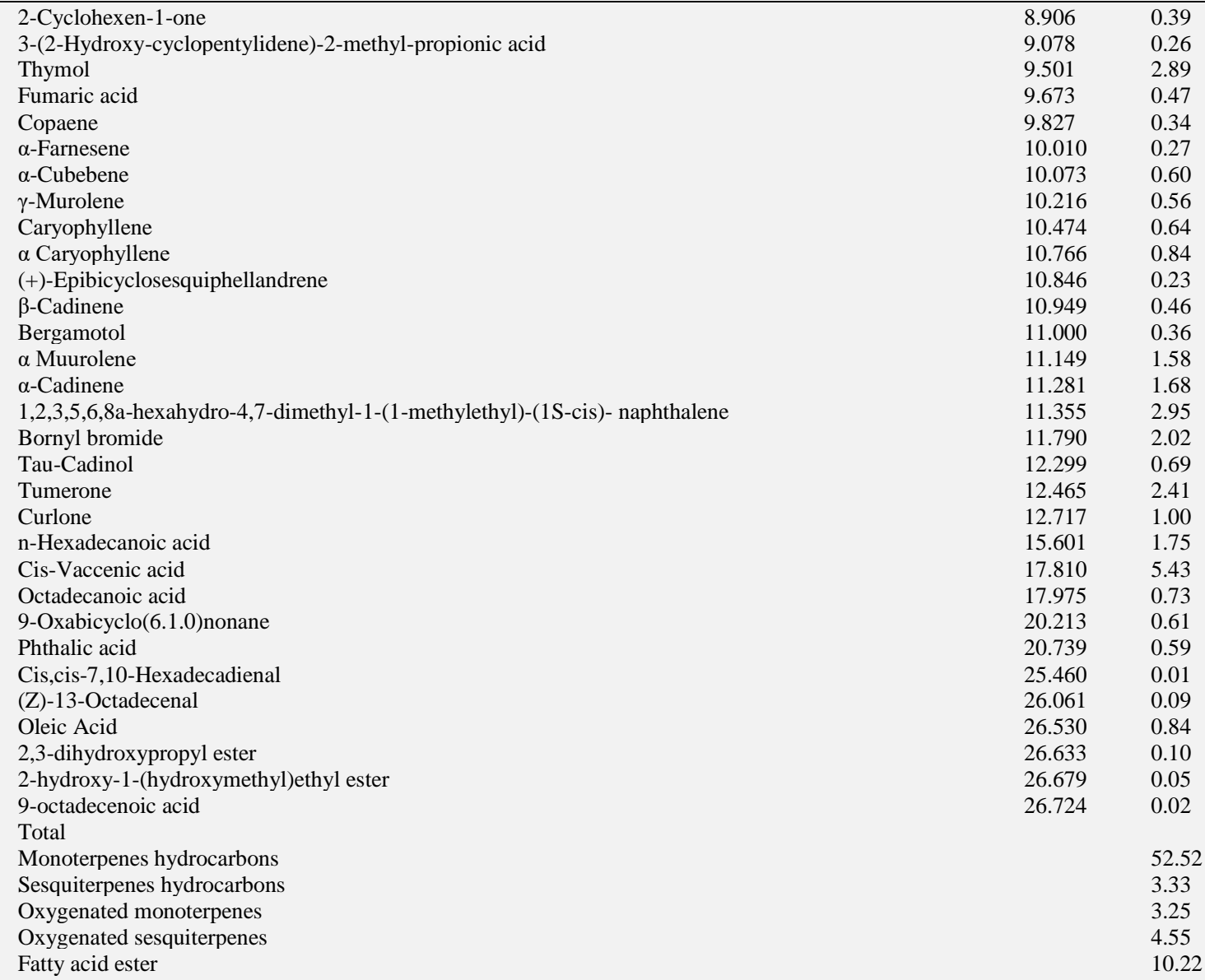

$9.078 \quad 0.26$

$9.501 \quad 2.89$

$9.673 \quad 0.47$

$9.827 \quad 0.34$

$10.010 \quad 0.27$

$10.073 \quad 0.60$

$10.216 \quad 0.56$

$10.474 \quad 0.64$

$10.766 \quad 0.84$

$10.846 \quad 0.23$

$10.949 \quad 0.46$

$11.000 \quad 0.36$

$11.149 \quad 1.58$

$11.281 \quad 1.68$

$11.355 \quad 2.95$

$11.790 \quad 2.02$

$12.299 \quad 0.69$

$12.465 \quad 2.41$

$12.717 \quad 1.00$

$15.601 \quad 1.75$

$17.810 \quad 5.43$

$17.975 \quad 0.73$

$20.213 \quad 0.61$

$20.739 \quad 0.59$

$25.460 \quad 0.01$

$26.061 \quad 0.09$

$26.530 \quad 0.84$

$26.633 \quad 0.10$

$26.679 \quad 0.05$

$26.724 \quad 0.02$

Table 2: The Essential Oil Constituents of Piper Nigrum

\begin{tabular}{|c|c|c|c|}
\hline $\mathrm{SN}$ & Compound & RT & $\%$ Peak Area \\
\hline 1 & 1,2-dimethyl-cyclohexane & 3.419 & 0.11 \\
\hline 2 & 2,6-dimethylheptane & 3.459 & 0.14 \\
\hline 3 & Octyl-cyclohexane & 3.510 & 0.73 \\
\hline 4 & 1,1,3-trimethyl-cyclohexane & 3.567 & 0.83 \\
\hline 5 & Dihydro-5,5-dimethyl-2(3H)-furanone & 3.768 & 0.14 \\
\hline 6 & 1,2,4-trymethyl-cyclohexane & 3.808 & 0.31 \\
\hline 7 & Piperidine & 3.916 & 0.17 \\
\hline 8 & Ethylbenzene & 4.002 & 0.66 \\
\hline 9 & 3-methyl-4-penten-1-ol & 4.071 & 0.43 \\
\hline 10 & p-Xylene & 4.157 & 2.65 \\
\hline 11 & 1-ethyl-2-methyl-cyclohexane & 4.409 & 0.73 \\
\hline 12 & 1,3-dimethyl-benzene & 4.517 & 0.94 \\
\hline 13 & 2,4-dimethylhexane & 4.655 & 0.83 \\
\hline 14 & 1-ethyl-2-methyl-cyclohexane & 4.706 & 0.19 \\
\hline 15 & Cyclohexane ethanol & 4.883 & 0.52 \\
\hline 16 & Propyl-cyclohexane & 5.061 & 0.58 \\
\hline 17 & $\alpha$-Pinene & 5.147 & 3.58 \\
\hline 18 & 3-ethyl-2-methylheptane & 5.250 & 0.41 \\
\hline 19 & Camphene & 5.330 & 0.31 \\
\hline 20 & N-Benzyl-2-phenethylamine & 5.427 & 0.60 \\
\hline 21 & 1,2,3-trimethylbenzene & 5.570 & 1.32 \\
\hline 22 & $\beta$-Pinene & 5.788 & 5.92 \\
\hline 23 & 1-ethyl-2-methyl-cyclohexane & 5.868 & 0.34 \\
\hline 24 & 1,2,3-trimethylbenzene & 5.994 & 1.79 \\
\hline 25 & 6-ethyl-2-methyl-decane & 6.097 & 0.62 \\
\hline 26 & $\alpha$-Phellandrene & 6.131 & 0.53 \\
\hline 27 & 3-Carene & 6.205 & 1.62 \\
\hline 28 & 1-ethyl-2,4-dimethylbenzene & 6.394 & 0.86 \\
\hline 29 & Limonene & 6.480 & 3.94 \\
\hline 30 & 3,7-dimethyl-1,3,6-Octatriene & 6.589 & 1.22 \\
\hline 31 & 3-isopropenyl-5,5-dimethyl-cyclopentene & 6.703 & 0.98 \\
\hline 32 & 2-ethyl-1,4-dimethyl-benzene & 6.823 & 0.37 \\
\hline 33 & (+)-4-Carene & 7.195 & 3.88 \\
\hline 34 & 3,7-dimethyl-1,6-octadien-3-ol & 7.413 & 7.08 \\
\hline 35 & 1.3,5,5-tetramethyl-1,3-cyclohexadiene & 7.659 & 0.31 \\
\hline 36 & 7-methyl-3-methylene & 8.191 & 0.20 \\
\hline 37 & 1-methyl-4-(1-methylethylidene)-cyclohexene & 8.357 & 1.30 \\
\hline 38 & 2,5,5-trimethyl-heptatriene & 9.724 & 0.54 \\
\hline 39 & $\alpha$-Cubebene & 9.833 & 0.65 \\
\hline
\end{tabular}




\begin{tabular}{|c|c|c|c|}
\hline 40 & Copaene & 10.096 & 3.25 \\
\hline 41 & 1-ethenyl-1-methyl-2,4-bis(1-methylethenyl)cyclohexane & 10.251 & 3.86 \\
\hline 42 & 1a,2,3,4,4a,5,6,7b-octahydro-1,1,4,7tetramethyl-1H-cycloprop€azulene & 10.417 & 2.98 \\
\hline 43 & Caryophyllene & 10.531 & 4.55 \\
\hline 44 & 4,11,11-trimethyl-8-methylenebiclo[7.2.0]undec-4-ene & 10.548 & 1.36 \\
\hline 45 & 1-methyl-5-methylene-8-(1-methylethyl)-1,6cyclodecadiene & 10.640 & 2.23 \\
\hline 46 & Ylangene & 10.708 & 2.11 \\
\hline 47 & 7,11-dimethyl-3-methylene-1,6,10dodecatriene & 10.811 & 4.29 \\
\hline 48 & 2,4-Quinolinediol & 11.057 & 4.74 \\
\hline 49 & 2,6-dimethyl-6-(4-methyl-3-pentenyl)biclo[3.1.1]hept-2-ene & 11.166 & 4.02 \\
\hline 50 & Cis-(-)-2,4a,5,6,9a-hexahydro-3,5,5,9tetramethyl $(1 \mathrm{H})$ benzocycloheptene & 11.275 & 1.76 \\
\hline 51 & 7,11-dimethyl-3-methylene-1,6,10dodecatriene & 11.515 & 8.32 \\
\hline 52 & Humulene & 11.618 & 0.27 \\
\hline 53 & 3,7,11-trimethyl-1,6,10-dodecatrien-3-ol & 11.681 & 0.68 \\
\hline 54 & Caryophyllene oxide & 11.899 & 1.66 \\
\hline 55 & 1H-cyclopropa[a]naphthalene & 11.973 & 0.20 \\
\hline 56 & Octahydro-1H-inden-1-one & 12.082 & 0.88 \\
\hline 57 & $\begin{array}{l}\text { 2,6,6,9-tetramethyl- } \\
\text { tricyclo[5-4.0.0(2,8)]undec-9-ene }\end{array}$ & 12.236 & 1.07 \\
\hline 58 & Aromadendrene & 12.293 & 0.50 \\
\hline 59 & Methyl methylphosphonofluoridate & 12.505 & 1.07 \\
\hline 60 & 2,3,3-trimethyl-2-(3-methyl-1,3-butadienyl)cyclohexanone & 12.648 & 1.24 \\
\hline \multirow[t]{7}{*}{61} & $\begin{array}{l}9,12 \text {-Octadecadienoic acid } \\
\text { TOTAL }\end{array}$ & 17.746 & 0.60 \\
\hline & Monoterpenes hydrocarbons & & 22.76 \\
\hline & Sesquiterpenes hydrocarbons & & 12.41 \\
\hline & Oxygenated monoterpenes & & 0.66 \\
\hline & Oxygenated sesquiterpenes & & 1.66 \\
\hline & Fatty acid ester & & 8.75 \\
\hline & Others & & 53.76 \\
\hline
\end{tabular}

Table 3: In Vitro Cholinesterase Inhibitory Activity $\mathrm{IC}_{50}(\mathrm{mg} / \mathrm{ml})$

\begin{tabular}{lll}
\hline & $\mathrm{IC}_{50}(\mathrm{mg} / \mathrm{ml})$ & \\
\hline & $\mathrm{AChE}$ & $\mathrm{BuChE}$ \\
M. Myristica & $0.205 \pm 0.060$ & $0.178 \pm 0.016$ \\
P. Nigrum & $0.272 \pm 0.018$ & $0.223 \pm 0.002$ \\
\hline
\end{tabular}

\subsection{In vitro anti-cholinesterase assay}

M. myristica exhibited a higher cholinesterase inhibition in both $\mathrm{AChE}$ and $\mathrm{BuChE}$ in a dose dependent manner, than P. nigrum. M. myristica essential oil at $416 \mu \mathrm{g} / \mathrm{ml}$ gave $78.72 \%$ while $\mathrm{P}$. nigrum gave $74.93 \% \mathrm{AChE}$ inhibition with $\mathrm{IC}_{50}$ values of $0.205 \pm 0.06$ and $0.272 \pm 0.18 \mathrm{mg} / \mathrm{ml}$, respectively. Similarly, at the same concentration M. myristica essential oil inhibited BuChE $89.19 \%$ while P. nigrum essential oil gave $84.96 \%$ and $\mathrm{IC}_{50}$ values of $0.178 \pm 0.016$ and $0.223 \pm 0.002 \mathrm{mg} / \mathrm{ml}$, respectively.

\subsection{Cognitive behavioral test}

\subsection{Morris water-maze}

The Escape Latency Time (ELT) of the first and the seventh day of treatment reflected the learning and acquisition behavior of animals, whereas, the ELT of the eighth day reflected retention of information or memory. Administration of Scopolamine hydrochloride $(0.4 \mathrm{mg} / \mathrm{kg}$, i.p), significantly prevented the reduction in the day seven ELT of the group administered scopocolamine only when compared to the control group ((-)scopolamine), indicating memory impairment. However, the animal in the group treated with $10 \mathrm{mg}$ Piracetam, 50, 100, and $200 \mathrm{mg} / \mathrm{kg}$ of the M. myristica and P. nigrum oil extracts showed a remarkable reduction $(\mathrm{p}<0.05)$ in ELT of the seventh day as well as eighth day in a dose dependent manner when compared with Scopolamine treated group, indicating significant improvement in learning and memory (Figure 1).

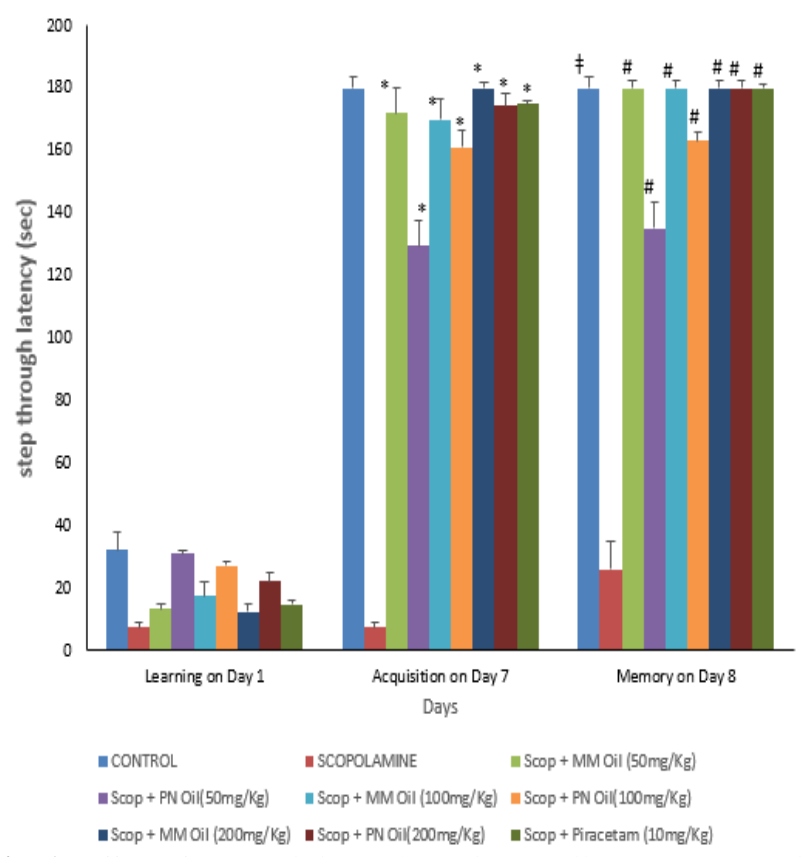

Fig. 1: Effect of M. Myristica and P. Nigrum Oil Extracts on Spatial Memory Performance In Mice Using the Morris Water-Maze Test. Values Are Expressed as Mean \pm S.E.M ( $=5$ in Each Group). Value with \# $\mathrm{P}$ $<0.05, * \mathrm{P}<0.05, \pm \mathrm{P}<0.05$ and $\ddagger \mathrm{P}<0.05$ Are Statistically Significant Compared to the Scopolamine Group.

\subsection{Step-through passive avoidance task}

The Step-Through Latency (SLT) of seventh and eighth day of the essential oil administered reflected the long-term memory of animals. The effect of Piracetam, M. myristica and P. nigrum oil extract on the performance of mice in PAV test is depicted in Figure 2 . In the Scopolamine treated group, there was a significant decrease $(\mathrm{p}<0.05)$ in the SLT when compared to the control group 
(saline) and that of the acquisition test of all groups, indicating improvement of memory. In the oil treated group, there was a significant $(\mathrm{P}<0.05)$ reversal of the Scopolamine induced amnesic effect at all doses of the extract in a dose dependent manner, including the $10 \mathrm{mg}$ Piracetam.
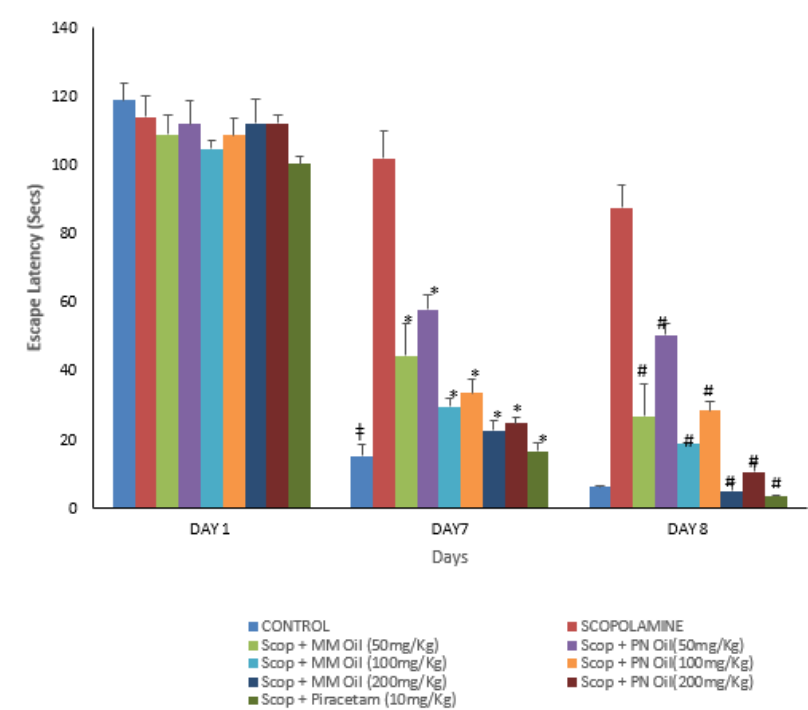

Fig. 2: Effect of M. Myristica and P.Nigrum Oil Extracts on Long Term Memory Performance in Mice Using Passive Avoidance Task. Values Are Expressed as Mean \pm S.E.M ( $\mathrm{N}=$ five in Each Group). Value with \# $\mathrm{P}<0.05$ $* \mathrm{P}<0.05, \mathrm{E} \mathrm{P}<0.05$ and $\neq \mathrm{P}<0.05$ Are Statistically Significant Compared to the Scopolamine Group.

\section{Discussion}

Enhancement of cholinergic activity through the inhibition of $\mathrm{AChE}$ is one of the major therapeutic strategies for $\mathrm{AD}$. Most of the USDA approved drugs such as tacrine have been used for mild cognitive disorders. These cholinesterase inhibitors attenuate the cholinergic deficit underlying the cognitive and neuropsychiatric dysfunction in AD patients (Lane, 2005). Particularly, therapeutic agents with dual inhibition of neuronal $\mathrm{AChE}$ and $\mathrm{BuChE}$, rather than agents that target selectively AChE only, have been speculated to bring about improved clinical outcomes (Andersen, 2004).

Results obtained clearly showed that the seeds of M. myristica and P. nigrum do possesses volatile compounds that exhibits both anticholinesterase and antioxidant activity to an extent, which renders them potentially useful as an adjuvant in the management of cognitive disorders such as in Alzheimer's disease. The GC-MS analysis of both essential oils from M. myristica and P. nigrum indicate the presence of terpenes, mainly monoterpenes hydrocarbons and oxygenated monoterpenes such as $\alpha$-Pinene, $\beta$-Pinene, $\alpha$-Phellandrene, $\alpha$-Caryophyllene, Bergamotol, Piperidine, $\alpha$-Cubebene, and Copaene as the major compounds.

Observations made in this study are consistent with that of a number of other studies of essential oils isolated by hydro-distillation from plants. Owokotomo and Ekundayo (2012) reported that the essential oil from seeds of M. myristica contained germacrene D-4-ol $(25.48 \%), \quad$ tricyclo[5.2.1]1,5dec-2-ene $\quad(13.35 \%), \quad \delta$-cadinene $(11.09 \%)$ and linalool $(15.10 \%)$ as major constituents while the dominant constituents of the stem-bark oil were $\gamma$-cadinene $(31.31 \%), \alpha$-elemene $(17.98 \%), \alpha$-cubebene $(6.70 \%)$ and $\gamma$-muurolene (5.94\%). Koudou et al. (2007) reported that the essential oil from the seeds of M. myristica contains mainly monoterpenoids $(93.2 \%)$ out of which $77.4 \%$ are monoterpene hydrocarbons and some sesquiterpenoids (5.8\%). The major constituents were $\alpha$-phellandrene $(34.4 \%)$ and p-cymene $(22.2 \%)$

Tchoumbougnang et al. (2009) studied the chemical composition of the essential oils obtained by hydro-distillation of different tissues of Piper capense, Piper guineense, Piper nigrum and Piper umbellatum grown in Cameroon and reported that oils from the fruits were rich in $\alpha$-pinene $(5.6-12.3 \%)$ and $\beta$-pinene $(6.7-59.3 \%)$. The other major constituents were sabinene (14.7\%) for P. capense, limonene $(15.8 \%)$ and $\beta$-caryophyllene $(20.8 \%)$ for P. guineense. Oil from the fruits of $\mathrm{P}$. nigrum contained sabinene $(11.2 \%), \delta$-3-carene $(18.5 \%)$, limonene $(14.7 \%)$ and $\beta$-caryophyllene $(12.8 \%)$ while that of P. umbellatum contained linalool $(14.4 \%)$ and (E)-nerolidol $(10.0 \%)$ as major constituents. Jirovetzet al. (2002) also reported the presence of germacrene D (11.01\%) and $\beta$-pinene $(10.02 \%)$ in P. nigrum seed oil. Arruda et al. (2012) reported that the essential oils obtained from the leaf of Hedychium gardnerianum contained monoterpenes, sesquiterpenes hydrocarbons which were responsible for both anti-cholinesterase and antioxidant properties observed. Sharififar et al. (2012) investigated the antioxidant and anticholinesterase effect of essential oil and methanolic extract of $\mathrm{Za}-$ taria multiflora Boiss and observed that the oil exhibited a high anticholinesterase activity ( $\mathrm{IC}_{50}=0.97 \pm 0.12 \mu \mathrm{g} / \mathrm{ml}$ ) which was comparable to physostigmine ( $\mathrm{IC}_{50}=0.13 \pm 0.02 \mu \mathrm{g} / \mathrm{ml}$ ). Ali et al. (2012) also investigated the composition, antimicrobial, antioxidant and anti-cholinesterase properties of leaf essential oil of Pulicaria stephanocarpa from Soqotra and observed that the oil elicited a $47 \%$ AChE inhibitory activity at a concentration of $200 \mu \mathrm{g} / \mathrm{ml}$. Carophyllene $(13.4 \%)$ a monoterpene hydrocarbon and nerolidol (8.5\%), $\alpha$-cadinol (8.2\%), spathulenol $(6.8 \%)$ which were oxygenated monoterpenes were the major components of the oil. The anticholinesterase activities of the essential oil of Salvia chionantha with $\beta$-caryophyllene $(8.71 \%)$, Germacrene $(25.03 \%)$, spathulenol $(5.86 \%)$ and humulene $(4.82 \%)$ as the major compounds have also been demonstrated. At a concentration of $500 \mu \mathrm{g} / \mathrm{ml}$ the oil elicited a moderate $\mathrm{AChE}(56.7 \pm 1.9 \%)$ and $\mathrm{BuChE}(41.7 \pm 2.9 \%)$ inhibitory activity.

The in vitro studies showed that the essential oil of M. myristica and $\mathrm{P}$. nigrum inhibited $\mathrm{AChE}$ and $\mathrm{BuChE}$ potently and reversibly, a phenomenon known as "dual cholinesterase inhibition". Studies have also shown that both $\mathrm{AChE}$ and $\mathrm{BuChE}$ hydrolyze $\mathrm{ACh}$ in vitro, however, ACh shows higher affinity for $\mathrm{AChE}$ than $\mathrm{BuChE}$ (Soreq and Seidman, 2001; Perry et al., 2003), BuChE has a preference for higher choline esters, such as butyrylcholine (BuCh) and other neuroactive peptides. Until recently, inhibition of AChE was the major focus of most researchers as the therapeutic strategy in the attenuation of diseases associated with cognitive decline. However, recent studies have evaluated the importance of BuChE and the key role it plays in regulating cognitive functions. Thus, the dual inhibition towards $\mathrm{AChE}$ and $\mathrm{BuChE}$ by both oils may be considered as a positive outcome that could boost the potentials of the plants as a candidate in the management of cognitive disorders associated with Alzheimer's disease.

The anti-amnesic and memory enhancing properties of the oil extract evaluated using two learning and memory paradigms, the Morris Water-Maze and the passive avoidance task shows that both essential oils reversed the scopolamine induced amnesia as indicated by the increase in the ELT in the Morris Water-Maze Test when compared to the scopolamine administered group and decrease in SLT in the passive avoidance task, indicating memory enhancing properties of the two oils. Several studies have shown the cognitive enhancing properties of natural product (plants) using various learning and memory paradigms.

The antiamnesic properties of essential oils have also been demonstrated by a number of investigators. Majlessi et al. (2012) in a study to demonstrate new neuro-protective plants for the management of $\mathrm{AD}$ reported that the essential oil of Zataria multiflora, a member of the Lamiaceae family, at a dose of $200 \mu 1 / \mathrm{kg}$ bwt was able to ameliorate the Amyloid-protein fragment-induced cognitive deficit in a Morris Water-Maze task. The investigators adduced the effect to the antioxidant, anti-inflammatory and anticholinesterase constituents of the plant.

Hritcu et al. (2012) investigated the antiamnesic effects of two different lavender essential oils from Lavandula angustifolia sp. angustifolia Mill. (Lamiaceae) and Lavandula hybrida Rev. (Lamiaceae) on male Wistar rats subjected to scopolamine $(0.7 \mathrm{mg} / \mathrm{kg})$ induced dementia. It was observed that chronic exposures to lavender essential oils (daily, for 7 continuous days) significantly improved the spatial memory performance in Y-Maze and Radial 
Arm-Maze tasks thus suggesting positive effects on memory formation. It was inferred from the study that multiple exposures to lavender essential oils could effectively reverse spatial memory deficits induced by dysfunction of the cholinergic system in the rat brain and might provide an opportunity for management of neurological abnormalities in dementia conditions.

\section{Conclusion}

We have shown that the M. myristica and P. nigrum essential oil contains terpenes and terpenoid such as $\alpha$-Pinene, $\beta$-Pinene, $\alpha$-Phellandrene, Caryophyllene and Copaene, among others with potent anti-cholinesterase and antioxidant activities. M. Myristica exhibited higher activity in all assays when compared to P. nigrum, and that these constituents could be acting alone or synergistically with others to bring about the anti-amnesic outcomes observed. In all, it can be suggested that the M. myristica and P. nigrum oils have health-promoting properties and as a dietary spice its use is advocated, especially by the elderly who are more prone to cognitive disorders. It could also be employed in the treatment and management of cognitive dysfunctions such as Alzheimer's and Parkinson's diseases. However, further studies on these essential oils using animal models of AD would be desirable.

\section{References}

[1] Ali, N A. A., Crouch, R. A., Al-Fatimi, M., Arnold, N., Teichert, A., Setzer, W. N. and Wessjohann, L. (2012). Chemical composition, antimicrobial, antiradical and anticholinesterase activity of the essential oil of Pulicariastephanocarpa from Soqotra. Natural Product Communications.7 (1): 113-116.

[2] Andersen, J. K. (2004). Oxidative stress in neurodegeneration: Cause or consequence? Nature Medicine, 10: 18-25. https://doi.org/10.1038/nrn1434.

[3] Anekonda, T. S. and Reddy, P. H. (2005). Can herbs provide a new generation of drugs for treating Alzheimer's disease? Brain Research Reviews50:

361

376 https://doi.org/10.1016/j.brainresrev.2005.09.001

[4] Arruda, M., Hugo, V., Nuno, R., Nuno R. N., José, S., Rosa, J., Nogueira, M. F. and Maria do Carmo B. (2012). Anti-acetylcholinesterase and Antioxidant Activity of Essential Oils from Hedychium gardnerianum Sheppard ex Ker-Gawl. Molecules. 17: 3082-3092 https://doi.org/10.3390/molecules17033082.

[5] Auld, D.S., Kornecook, T.J., Bastianetto, S., Quirion, R., 2002. Alz heimer's diseaseandthe basal forebrain cholinergic system: relations to beta-amyloid peptides, cognition, and treatment strategies. Prog. Neurobiol.68, 209-245. https://doi.org/10.1016/S0301 0082(02)00079-5.

[6] Ballatore, C., Lee, V.M., Trojanowski, J.Q., 2007. Tau-mediated neurodegeneration inAlzheimer's disease and related disorders. Nat. Rev. Neurosci. 8, 663-672 https://doi.org/10.1038/nrn2194.

[7] Bartus, R.T., 2000. On neurodegenerative diseases, models, and treatment strategies: lessons learned and lessons forgotten a generation following the cholinergic hypothesis. Exp. Neurol. 163, 495529. https://doi.org/10.1006/exnr.2000.7397.

[8] Bourin, M., Ripoll, N., Dailly, E., 2003. Nicotinic receptors and Alzheimer's disease. Curr. Med. Res. Opin.19, 169-177. https://doi.org/10.1185/030079903125001631.

[9] Caughey, B. and Lansbury, P.T., 2003. Protofibrils, pores, fibrils, and neurodegeneration:separating the responsible protein aggregates from the innocent bystanders.Annu. Rev. Neurosci.26, 267-298. https://doi.org/10.1146/annurev.neuro.26.010302.081142.

[10] Celone, K.A., Calhoun, V.D., Dickerson, B.C., Atri, A., Chua, E.F. Miller, S.L., DePeau, K., Rentz, D.M., Selkoe, D.J., Blacker, D., Albert, M.S., Sperling, R.A., 2006. Alterations in memory networks in mild cognitive impairment and Alzheimer's disease: an independent component analysis. J. Neurosci.26, 10222-10231. https://doi.org/10.1523/JNEUROSCI.2250-06.2006.

[11] Das, A., Shanker, G., Nath, C., Pal, R., Singh, S. and Singh, H. K. (2002). A comparative study in rodents of standardized extracts of Bacopamonniera and Ginkgo biloba anticholinesterase and cognitive enhancing activities. Pharmacological and BiochemicalBehaviour. 73:893-900 https://doi.org/10.1016/S0091-3057(02)00940-1.
[12] Dheen, S.T., Kaur, C., Ling, E.A., 2007. Microglial activation and its implications in the brain diseases. Curr. Med. Chem. 14, 11891197. https://doi.org/10.2174/092986707780597961.

[13] Dhingra, D., Parle, M. and Kulkarni, S. K. (2004). Memory enhancing activity of Glycyrrhiza glabra in mice. Journal of Ethnopharmacology.91: 361-365 https://doi.org/10.1016/j.jep.2004.01.016

[14] El-Hela, A. and Abdullah, A. (2010). Chemical Composition and Biological Activities of Essential Oil of Salvia acetabulosa L. Grown in Egypt. Journal of Applied Sciences Research. 6(6): 690-695.

[15] Ellman, G. L., Courtney, K. D., Andres, V. and Featherstone, R. M. (1961). A new and rapid colorimetric determination of acetylcholinesterase activity. Biochemical Pharmacology.7:88-95. https://doi.org/10.1016/0006-2952(61)90145-9.

[16] Figueiro, M., Ilha, J., Linck, V.M., Herrmann, A.P., Nardin, P., Menezes, C.B., Achaval,M., Goncalves, C.A., Porciuncula, L.O., Nunes, D.S., Elisabetsky, E., 2011. The Amazonian herba Marapuama attenuates cognitive impairment and neuroglial degeneration in a mouse Alzheimer model. Phytomedicine 18, 327-333. https://doi.org/10.1016/j.phymed.2010.07.013.

[17] Hancianu, M., Cioanca, O., Mihasan, M. and Hritcu, L. (2013). Neuroprotective effects of inhaled lavender oil on scopolamine-induced dementia via anti-oxidative activities in rats. Phytomedicine.20 (5) 446-452. https://doi.org/10.1016/i.phymed.2012.12.005.

[18] Hefco, V., Yamada, K., Hefco, A., Hritcu, L., Tiron, A., Olariu, A., Nabeshima, T., 2003. Effects of nicotine on memory impairment induced by blockade of muscarinic, nicotinic and dopamine D2 receptors in rats. Eur. J. Pharmacol. 474, 227-232 https://doi.org/10.1016/S0014-2999(03)02034-X.

[19] Hritcu, L., Cioanca, O. and Hancianu, M. (2012). Effects of lavender oil inhalation on improving scopolamine-induced spatial memory impairment in laboratory rats. Phytomedicine. 19(6): 529-534 https://doi.org/10.1016/j.phymed.2012.02.002.

[20] Jirovetz Leopold, Gerhard Buchbauer, Martin Benoit Ngassoum, Margit Geissler. (2002). A roma compound analysis of Piper nigrum and Piper guineense essential oils from Cameroon using solid-phase microextraction-gas chromatography, solid-phase microextractiongas chromatography-mass spectrometry and olfactometry. Journal of Chromatography A, 976 265-275 https://doi.org/10.1016/S00219673(02)00376-X

[21] Kashani, M.S., Tavirani, M.R., Talaei, S.A., Salami, M., 2011. Aqueous extract of lavender (Lavandula angustifolia) improves the spatial performance of a rat model of Alzheimer's disease. Neurosci. Bull.27, 99-106. https://doi.org/10.1007/s12264-011-1149-7.

[22] Knobloch, M., Konietzko, U., Krebs, D.C., Nitsch, R.M., 2007. Intracellular Abeta and cognitive deficits precede beta-amyloid deposition in transgenic arc-Abeta mice. Neurobiol. Aging 28, 1297 1306. https://doi.org/10.1016/j.neurobiolaging.2006.06.019.

[23] LaFerla, F.M., Green, K.N., Oddo, S., 2007. Intracellular beta-amyloid in Alzheimer'sdisease. Nat. Rev. Neurosci. 8 499-509. https://doi.org/10.1038/nrn2168.

[24] Lahiri, D.K., Farlow, M.R., Greig, N.H., Sambamurti, K., 2002. Current drug targets for Alzheimer's disease treatment. Drug Develop. Res. 56, 267-281. https://doi.org/10.1002/ddr.10081.

[25] Lane, R. M., Potkin, S. G. and Enz, A. (2005).Targeting acetylcholinesterase and butyrylcholinesterase in dementia. The International Journal of Neuropsychopharmacology. 46(3): 123-129.

[26] Majlessi, N., Choopani, S., Kamalinejad, M. and Azizi, Z. (2012). Amelioration of $\beta$-amyloid -induced cognitive deficits by Zataria multiflora Bloiss. Essential oil in a rat model of Alzheimer;s disease. CNS Neuroscience and Therapeutics.18 (4): 295-301. https://doi.org/10.1111/j.1755-5949.2011.00237.x.

[27] Morris, R. (1984). Developments of a water-maze procedure for studying spatial learning in the rat. Journal of Neuroscience Methods.11: 47-60. https://doi.org/10.1016/0165-0270(84)90007-4.

[28] Natarajan, S., Shunmugiah, K, P. and Kasi, P. D. (2013). Plants traditionally used in age-related brain disorders (dementia): An ethnopharmacological survey. Pharmaceutical Biology.51 (4): 492 523. https://doi.org/10.3109/13880209.2012.738423.

[29] Obuotor, E. M. (2004). The mode of action of Ichthtotoxic principles in Raphia hookeri fruit. Ph.D Thesis. Obafemi Awolowo University, Ile-Ife.

[30] Owokotomo, I. A. and Ekundayo, O. (2012). Comparative Study of the Essential Oils of Monodora Myristica from Nigeria. European Chemical Bulletin, Vol 1, No 7 (2012)

[31] Perry, N. S., Bollen, C., Perry, E. K. and Ballard, C. (2003). Salvia for dementia therapy: review of pharmacological activity and pilot tolerability clinical trial. Pharmacology, Biochemistry and Behavior. 75 651-659. https://doi.org/10.1016/S0091-3057(03)00108-4. 
[32] Pimplikar, S.W., 2009. Reassessing the amyloid cascade hypothesis of Alzheimer'sdisease. Int. J. Biochem. Cell Biol. 41, 1261-1268. https://doi.org/10.1016/j.biocel.2008.12.015.

[33] Rauk, A., 2009. The chemistry of Alzheimer's disease. Chem. Soc. Rev. 38, 2698-2715. https://doi.org/10.1039/b807980n

[34] Savelev, S., Okello, E., Perry, N. S. L., Wilkins, R. M. and Perry, E. K. (2003). Synergistic and antagonistic interactions of anticholinesterase terpenoids in Salvia lavandulaefolia essential oil. Pharmacology, Biochemistry and Behavior.75 661-668. https://doi.org/10.1016/S0091-3057(03)00125-4.

[35] Sennuga, A. T. (2007). A Comparative Study of the Anti-cholinesterase and Cognitive Enhancing Properties of Morinda lucida Benth and Croton zambesicus Muell. Arg. in Adult Mice. M.Sc Thesis. Obafemi Awolowo University, Ile-Ife.

[36] Sharififar, F., Mirtajadini, M., Azampour, M. J. and Zamani, E (2012). Essential oil and methanolic extract of Zataria multiflora Boiss with anticholinesterase effect. Pakistan Journal of Biological Sciences, 15 (1): 49-53. https://doi.org/10.3923/pjbs.2012.49.53.

[37] Soreq, H. and Seidman, S. (2001). Acetylcholinesterase new roles for an old actor. National Review of Neuroscience.2 294-302. https://doi.org/10.1038/35067589.

[38] Strohmeyer, R., Rogers, J., 2001. Molecular and cellular mediators of Alzheimer's disease inflammation. J. Alzheimers Dis. 3, 131-157. https://doi.org/10.3233/JAD-2001-3118.

[39] Sun, X.L., Ito, H., Masuoka, T., Kamei, C., Hatano, T., 2007. Effect of Polygala tenuifolia root extract on scopolamine-induced impairment of rat spatial cognition in an eight-arm radial maze task. Biol. Pharm. Bull.30, 1727-1731. https://doi.org/10.1248/bpb.30.1727.

[40] Syad, A. N., Karutha P. S. and Pandima D. K. (2012). Assessment of Anticholinesterase Activity of Gelidiella acerosa: Implications for Its Therapeutic Potential against Alzheimer's disease. Evidence-Based Complementary and Alternative Medicine. $2012.1-8$. https://doi.org/10.1155/2012/497242.

[41] Tchoumbougnang, F., Jazet, D. P. M., Sameza, L. M., Fombotioh, N., Wouatsa, N. A. V., Amvam, Z. P. H. and Menut, C. (2009). Comparative essential oils composition and insecticidal effect of different tissues of Piper capense L. Piper guineense Schum. Et Thonn., Piper nigrum L. and Piperumbellatum L. grown in Cameroun. African Journal of Biotechnology. 8 (3):424-431.

[42] Tuppo, E.E., Arias, H.R., 2005. The role of inflammation in Alzheimer's disease. Int.J. Biochem. Cell Biol. 37, 289-305.

[43] Ustun, O., Fatma, S. S., Mine, K, Ilkay, E. O., Murat, K. and Kemal, H. C. B. (2012). Investigation on chemical composition, anticholinesterase and antioxidant activities of extracts and essential oils of Turkish Pinus species and pycnogenol. Industrial Crops and Products.38: 115- 123 https://doi.org/10.1016/j.indcrop.2012.01.016.

[44] Wang, Q., Sun, L.-H., Jia, W., Liu, X.-M., Dang, H.-X., Mai, W.-L., Wang, N., Steinmetz, A., Wang, Y.-Q., Xu, C.-J., 2010. Comparison of ginsenosides $\operatorname{Rg} 1$ and $\mathrm{Rb} 1$ for their effects on improving scopolamine-induced learning and memory impairment in mice. Phytother. Res. 24, 1748-1754 https://doi.org/10.1002/ptr.3130.

[45] Yamin, G., 2009. NMDA receptor-dependent signaling pathways that underlie amyloid beta-protein disruption of LTP in the hippocampus. J. Neurosci.87, 1729-1736. 